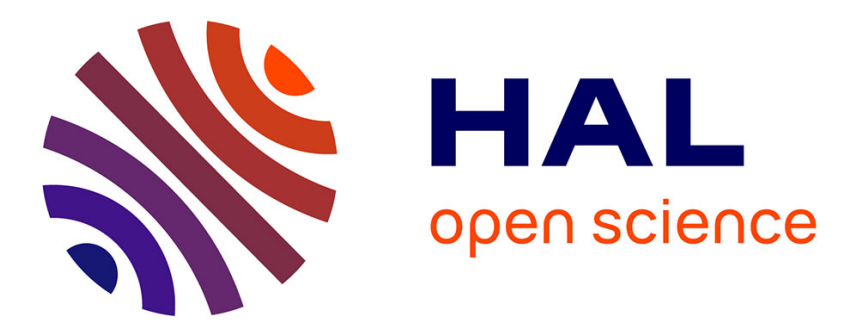

\title{
Seasonal oxygen isotope variations in freshwater bivalve shells as recorders of Amazonian rivers hydrogeochemistry
}

B. Gaillard, Claire E. Lazareth, H. Lestrelin, E. Dufour, R.V. Santos, C.E.C. Freitas, Marc Pouilly

\section{To cite this version:}

B. Gaillard, Claire E. Lazareth, H. Lestrelin, E. Dufour, R.V. Santos, et al.. Seasonal oxygen isotope variations in freshwater bivalve shells as recorders of Amazonian rivers hydrogeochemistry. Isotopes in Environmental and Health Studies, 2019, 55 (6), pp.511-525. 10.1080/10256016.2019.1666120 . hal-02314885

\section{HAL Id: hal-02314885 \\ https://hal.science/hal-02314885}

Submitted on 20 Oct 2019

HAL is a multi-disciplinary open access archive for the deposit and dissemination of scientific research documents, whether they are published or not. The documents may come from teaching and research institutions in France or abroad, or from public or private research centers.
L'archive ouverte pluridisciplinaire HAL, est destinée au dépôt et à la diffusion de documents scientifiques de niveau recherche, publiés ou non, émanant des établissements d'enseignement et de recherche français ou étrangers, des laboratoires publics ou privés. 


\title{
Seasonal oxygen isotope variations in freshwater bivalve shells as recorders of Amazonian rivers hydrogeochemistry
}

\author{
Blandine Gaillard ${ }^{\mathrm{a}}$, Claire E. Lazareth ${ }^{\mathrm{a}}$, Hugo Lestrelin ${ }^{\mathrm{a}}$, Elise Dufour ${ }^{\mathrm{b}}$, Roberto V. Santos ${ }^{\mathrm{c}}$, \\ Carlos E. C. Freitas ${ }^{d}$, and Marc Pouilly ${ }^{a}$

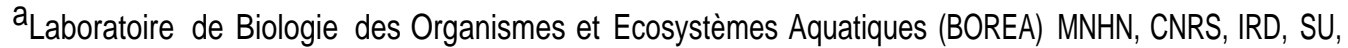 \\ UCN, UA, Paris, France \\ ${ }^{b}$ Archéozoologie, Archéobotanique: Sociétés, Pratiques et Environnements (AASPE), Muséum \\ National d'Histoire Naturelle, CNRS, Paris, France \\ CLaboratório de Geocronologia, Instituto de Geociências, Universidade de Brasilia, Brasilia, Brazil \\ dDepartamento de Ciências Pesqueiras, Universidade Federal do Amazonas (UFAM), Manaus, Brazil
}

*CONTACT Blandine Gaillardｂlandine.gaillard5@gmail.com

\section{KEYWORDS}

Amazon basin; freshwater, bivalve shells; hydroclimate; isotope ecology; isotope hydrology; oxygen isotopes

\begin{abstract}
Freshwater bivalve shell oxygen isotope values $\left(\delta^{18} \mathrm{O} s\right)$ may act as a recorder of river $\delta^{18} \mathrm{O}$ variations that can then be interpreted in terms of hydrology (e.g. precipitationevaporation balance, precipitation and river discharge patterns). We investigated the potential of this proxy measured across the hinge of South American unionid shells: Anodontites elongatus collected in Peru and $A$. trapesialis in Brazil. The isotopic signatures were reproducible between individuals of the same species. $A$. trapesialis clearly showed a strong $\delta^{18} \mathrm{O}$ s cyclicity in accordance with its growth patterns while $A$. elongatus presented less clear $\delta^{18} \mathrm{O}$ s with lower amplitude. We confirm that the deposition of successive growth lines and increments is annual, with growth line corresponding to the wet season. Also, we suggest that low amplitude of $\delta^{18} \mathrm{O}$ s in the A. elongatus shells indicates a habitat close to the river while large amplitude of $\delta^{18} \mathrm{O}$ cycles observed in $A$. trapesialis shells would reflect a floodplain lake habitat, seasonally disconnected from the river and thus subjected to higher seasonal fluctuations in water $\delta^{18} \mathrm{O}$. Considering these promising first results, future studies could be directed towards the use of fossil shells to reconstruct the past and present hydrological and geochemical conditions of the Amazon.
\end{abstract}

\section{Introduction}

The Amazon basin holds several world records: the Amazon River is the world's largest one included in the largest basin in the world, supporting the largest tropical forest and diversity of freshwater fish species. This continental hydrosystem participates significantly to the global hydrological, climatic, and carbon cycles, and its contribution to the ocean in terms of sediment is also considerable [1,2]. Moreover, it is the supplier of multiple ecosystemic services to the human populations such as food, incomes via fishing, and transport [3]. Climate change has, however, already impacted the hydrology of this hydrosystem, e.g. in increasing extreme hydrological event occurrences [4-6]. It is thus crucial to better understand the functioning of this system, its temporal variability, and the modifications induced by the global and regional changes, to define optimal strategies of sustainable development.

To this end, a geochemical and hydrological monitoring programme was launched in the 
Amazonian basin in 2003 (HYBAM observatory; www.ore-hybam.org). Indeed, geochemical tools have been used to define hydrogeochemical zones within the basin to trace the water sources of the rivers and their evolutions and to understand erosion processes and global geochemical cycles [7-10]. These geochemical tools are also of paramount importance in ecology and in the following-up of fish migration or river pollution, for example [11-14]. However, due to the huge extension of this basin - between $5^{\circ} \mathrm{N}$ and $20^{\circ} \mathrm{S}$ and from the Andes to the Atlantic Ocean, covering approximately 7,500,000 km2 [15] - the instrumental monitoring is expensive and demands a complex logistic, particularly in remote areas [7,16]. The dynamic geological evolution of the basin, together with the pronounced seasonal variation of rainfall and hydrological regime, lead to the formation of three landscapes characterised by distinct hydrology and hydrological variations: (1) the 'Terra Firme', corresponding to land that is never flooded, (2) the 'Varzea' floodplains including secondary channels, lakes, and lands which are permanently or temporarily inundated according to the hydrological regime, and (3) the main channel of the river that corresponds to permanent flowing water body. Because of the huge spatial coverage and the complexity of the Amazon basin, its hydrology and geochemistry is not fully known [11].

Because of the dynamic evolution of the Andes, the Amazon basin and its drainage system are under permanent changes. To better understand and track these changes, including river channel migration and floodplain development, it is necessary to develop high-resolution environmental proxies such as those based on aquatic mollusc shells. Indeed, these organisms may record endogenous and environmental information, from seasonal to inter-annual scales, both for present day or past periods [17-20]. The potential of freshwater bivalve shells as an archive of geochemical and environmental conditions of their habitats (e.g. precipitation and river discharge patterns, (paleo)temperature, pollution) has been recognised in many studies [21-25]. One powerful proxy is the oxygen isotope composition $\left(\delta^{18} \mathrm{O} s 1\right)$, which records rainfall or river discharge patterns in such mollusc shells $[24,26,27]$. In contrast to studies that use shells as paleoclimatic proxies in the Amazon [28-31], only one study has addressed the potential of modern amazonian freshwater bivalve shells as bio-archives of environmental conditions [22].

In an attempt to push forward the use of shells as environmental proxy in the Amazon, we studied oxygen isotopes of modern Anodontites sp. shells that have grown under distinct environmental conditions in the Amazon basin. Besides addressing intraspecies reproducibility, we have also evaluated how the observed oxygen isotope variations and patterns can be used to determine the hydrological condition of the environment in which they have grown.

\section{Material and method}

\subsection{Study sites - environmental characteristics}

The Unionidae shells were collected empty in 2015 by local people in two South American sites. We observed that, in such environments, shells degrade rapidly after death of the animal. Even during the animal's lifetime, the periostracum on the hinge can be locally damaged (pers. comm., C.E. Lazareth). Here, since the shells were all in the same well-preserved state, presumably they have died recently. Two A. trapesialis shells were collected in a lake bordering the Rio Solimões close to the Ilha Paciencia that is located between Manacapuru and Manaus in Brazil (Table 1, Figure 1). This lake, located in the annual active band of the river, at around $1 \mathrm{~km}$ from the mainstream at low water level, is disconnected from the Rio Solimões several months per year (4-6 months). Note that the so-called Solimões River (Brazil) is the downstream part name of the Amazonas River (Peru). Two A. elongatus shells were collected in a marginal lake along the Rio Amazonas close to lquitos in Peru (Table 1, Figure 1). Unfortunately, the exact distance of the lake from the mainstream is unknown. On each site, shells with similar size were chosen to avoid any age-related isotope fractionation effect.

\footnotetext{
${ }^{1}$ The letters indexing $\mathrm{O}$ in the text mean: S-shell, R-river, $\mathrm{P}$-precipitation, AR-aragonite, $\mathrm{W}$-water.
} 
Table 1. Anodontites spp. shell sampling location and size (L: length and $\mathrm{H}$ : height).

\begin{tabular}{|c|c|c|c|c|c|c|c|}
\hline \multirow[b]{2}{*}{ Species } & \multicolumn{4}{|c|}{ Sampling location } & \multicolumn{3}{|c|}{ Shell size } \\
\hline & Country & Site & Latitude & Longitude & Specimen & $\mathrm{L}(\mathrm{mm})$ & $\mathrm{H}(\mathrm{mm})$ \\
\hline Anodontites trapesialis & Brazil & Ilha da Paciencia & $3^{\circ} 19^{\prime} 21.0^{\prime \prime S}$ & $60^{\circ} 16^{\prime} 36.0^{\prime \prime} \mathrm{W}$ & At-1 & 17.0 & 9.1 \\
\hline Anodontites elongatus & Peru & Iquitos & $3^{\circ} 44^{\prime} 32.2^{\prime \prime S}$ & $73^{\circ} 13^{\prime} 31.2^{\prime \prime} \mathrm{W}$ & $\begin{array}{l}\text { At-2 } \\
\mathrm{Ae}-1 \\
\mathrm{Ae}-2\end{array}$ & $\begin{array}{l}16.8 \\
05.0 \\
05.8\end{array}$ & $\begin{array}{l}9.5 \\
3.5 \\
3.6\end{array}$ \\
\hline
\end{tabular}

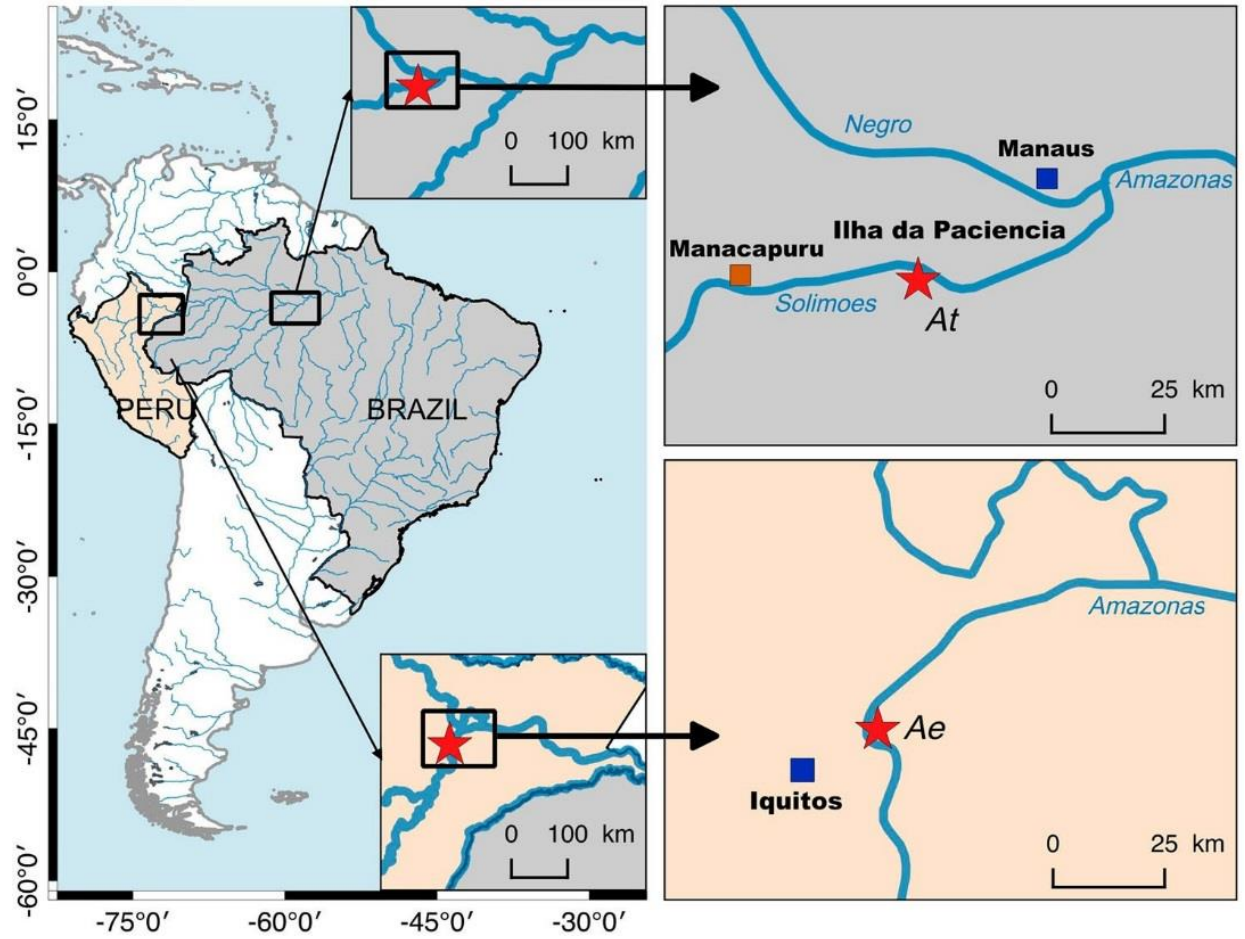

Figure 1. Shells sampling locations (red stars): Anodontites elongatus (Ae) at lquitos, Peru, and $A$. trapesialis (At) at Ilha da Paciencia, Brazil. Environmental data were taken from GNIP (blue square) and GNIR (orange square) stations. See text for details.

The amount of precipitation as well as the oxygen isotope values of rivers and precipitation $\left(\delta^{18} \mathrm{O}_{R}\right.$ and $\delta^{18} \mathrm{O}_{\mathrm{P}}$ respectively) were taken from the International Atomic Energy Agency's (IAEA) Global Networks of Isotopes in Precipitation and Rivers (GNIP, GNIR; http://www.iaea.org/water) (Table 2). For the Rio Solimões (Brazil), river water oxygen isotope values come from the Manacapuru station (distant from around $80 \mathrm{~km}$ from the shells sampling location) and precipitation amount and $\delta^{18} \mathrm{O}_{\mathrm{P}}$ values from Manaus (about $35 \mathrm{~km}$ from the shells sampling location) (Figure 1, Table 2). At this place, during the dry season, which lasts for about 3 months around August, precipitation is $<100 \mathrm{~mm}$ month $^{-1}$ and the $\delta^{18} \mathrm{O}_{\mathrm{p}}$ value is higher than $-2 \%$ (vs. Vienna Standard Mean Ocean Water, $\mathrm{V}-\mathrm{SMOW}$ ). During the wet season (5 months around March), precipitation is $>250 \mathrm{~mm}$ month $^{-1}$ and $\delta^{18} \mathrm{O}_{P}$ values are the lowest of the year (<-4 \%o V-SMOW) (Figure 2(a)). Accordingly, the oxygen isotope values of the river water $\left(\delta^{18} \mathrm{O}_{R}\right)$ of the Rio Solimões vary seasonally with most positive values ( -4.91 and $-5.65 \%$ V-SMOW) during September and October and most negative ones (-5.77 and $-6.69 \%$ V-SMOW) during May and June 
(Figure 2(a)). For the Rio Amazonas site (Peru), the precipitation data (amount and $\delta^{18} \mathrm{O}_{\mathrm{p}}$ ) were taken from the lquitos station (about $20 \mathrm{~km}$ from lquitos city; Figure 1, Table 2). The precipitation amount ranges from $156 \mathrm{~mm}$ month $^{-1}$ during the dry season (August) to more than $500 \mathrm{~mm}$ month $^{-1}$ during the wet one (April, Figure 2(b)). The lowest $\delta^{18} \mathrm{O}_{\mathrm{P}}$ values $\left(\delta^{18} \mathrm{O}_{\mathrm{P}}=-8.89 \pm 4.07 \%\right.$ March and $-7.06 \pm 3.23 \%$ October, V-SMOW) occur during the wet seasons and the highest $\left(\delta^{18} \mathrm{O}_{\mathrm{p}}=-1.87 \pm 0.96 \%\right.$ August and $-4.44 \pm 1.62$ $\%$ February, V-SMOW) during the wet one (Figure 2(b)).

Table 2 Environmental data used in this study. Monthly precipitation and $\delta^{18} \mathrm{O}$ are from the GNIP (Global Network of Isotopes in Precipitation) database, and $\delta^{18} \mathrm{O}_{\mathrm{R}}$ from GNIR (Global Network of Isotopes in Rivers). The mean seasonal range is expressed as the mean (SD) difference between the highest $(\max )$ and the lowest $(\min )$ monthly mean. SD: standard deviation. See figure 1 for stations location.

\begin{tabular}{|c|c|c|c|c|}
\hline & & $\begin{array}{l}\text { Precipitation } \\
(\mathrm{mm})\end{array}$ & $\begin{array}{c}\delta^{18} \mathrm{Op}_{p} \\
(\% 0)\end{array}$ & $\begin{array}{c}\delta^{18} \mathrm{O}_{\mathrm{R}} \\
(\% 0)\end{array}$ \\
\hline \multirow{5}{*}{ Brazil } & Station & \multirow{2}{*}{\multicolumn{2}{|c|}{$\begin{array}{l}\text { Manaus } \\
\text { monthly }\end{array}$}} & $\begin{array}{l}\text { Rio Solimões, } \\
\text { Manacapuru }\end{array}$ \\
\hline & Resolution & & & $1-3$ per month \\
\hline & Period & $\begin{array}{c}1965-1990 \\
(n=303)\end{array}$ & $\begin{array}{c}1965-1990 \\
(n=187)\end{array}$ & $2000-2004(n=56)$ \\
\hline & Mean (SD) & $191.3(122.9)$ & $-4.18(2.71)$ & $-5.59(0.65)$ \\
\hline & $\begin{array}{c}\text { Mean seasonal } \\
\text { Range }\end{array}$ & 277.3 & 5.38 & 1.78 \\
\hline \multirow{3}{*}{ Peru } & $\begin{array}{c}\text { Station } \\
\text { Resolution }\end{array}$ & \multicolumn{2}{|c|}{$\begin{array}{l}\text { lquitos } \\
\text { monthly }\end{array}$} & \\
\hline & $\begin{array}{c}\text { Period } \\
\text { Mean (SD) }\end{array}$ & $\begin{array}{c}2007-2012 \\
(n=50) \\
382.3(218.2)\end{array}$ & $\begin{array}{c}2006-2012 \\
(n=54) \\
-5.94(3.37)\end{array}$ & No data \\
\hline & $\begin{array}{c}\text { Mean Seasonal } \\
\text { Range }\end{array}$ & 360.6 & 7.03 & \\
\hline
\end{tabular}

\subsection{Shell preparation}

Shell lengths and heights are reported in Table 1. We prepared the shell hinges for analysis since the growth pattern (succession of increment and growth lines) is clearer than in other parts of the shell. In addition, hinge represents the whole life, while also limiting the number of samples to collect and analyse to obtain several years of seasonal isotope profile. All shells were cleaned and air-dried before further preparation. One valve of each specimen was cut along the axis of maximum growth (Figure 3(b)) using a water diamond saw (Isomet $5000 \AA$, Buehler), and afterwards a slice about $5 \mathrm{~mm}$ thick was cut from these half-valves (Figure 3(c)). Since the small and thin $A$. elongatus shells could have broken during preparation, one valve of each specimen was embedded in epoxy resin (Epoxicure $\AA^{\circledR}$, Buehler) before cutting. The $A$. trapesialis cross-sections were manually broken and hinges were embedded in epoxy resin. Finally, embedded hinge cross-sections were polished using grinding disks with decreasing grain size and diamond suspensions (down to $1 \mu \mathrm{m}$ ) on polishing cloths. 


\section{BRAZIL}

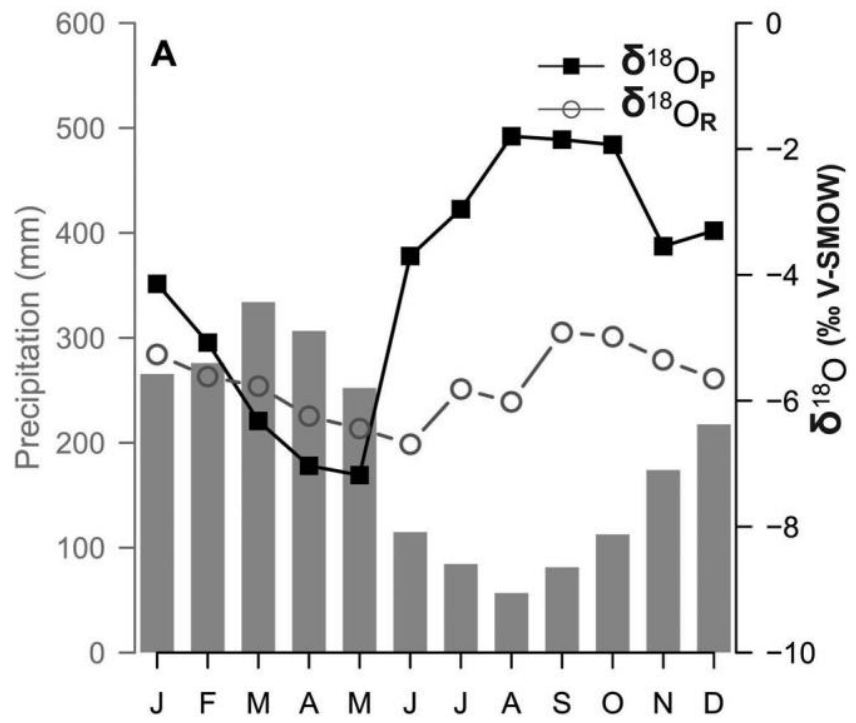

\section{PERU}

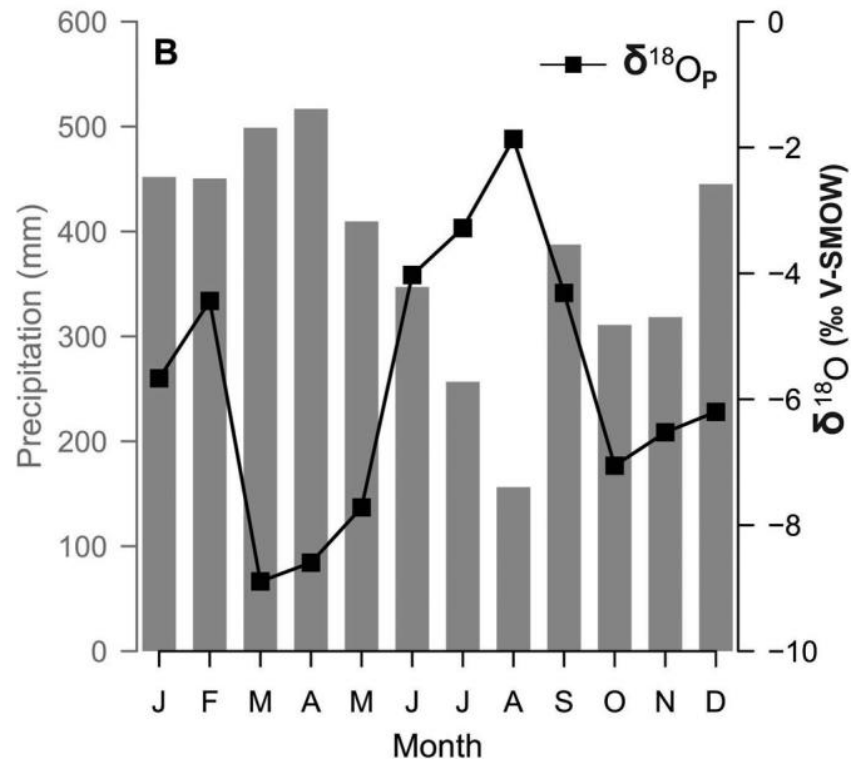

Figure 2. Seasonal precipitation variability and $\delta^{18} \mathrm{O}$ values of precipitations and river water (in \%o VSMOW) for the two sites: (A) in Brazil, mean monthly precipitation (grey bars) and isotopic monthly variability in precipitation $\left(\delta^{18} \mathrm{O}_{\mathrm{p}}\right.$, black squares) at Manaus and $\delta^{18} \mathrm{O}$ values for the Rio Solimões $\left(\delta^{18} \mathrm{O}_{\mathrm{R}}\right.$, open circles) at Manacapuru and (B) in Peru, mean monthly precipitation (grey bars) and isotopic monthly variability in precipitation $\left(\delta^{18} \mathrm{O}_{\mathrm{p}}\right.$, black squares) at lquitos. See Figure 1 for station locations and data sources. 


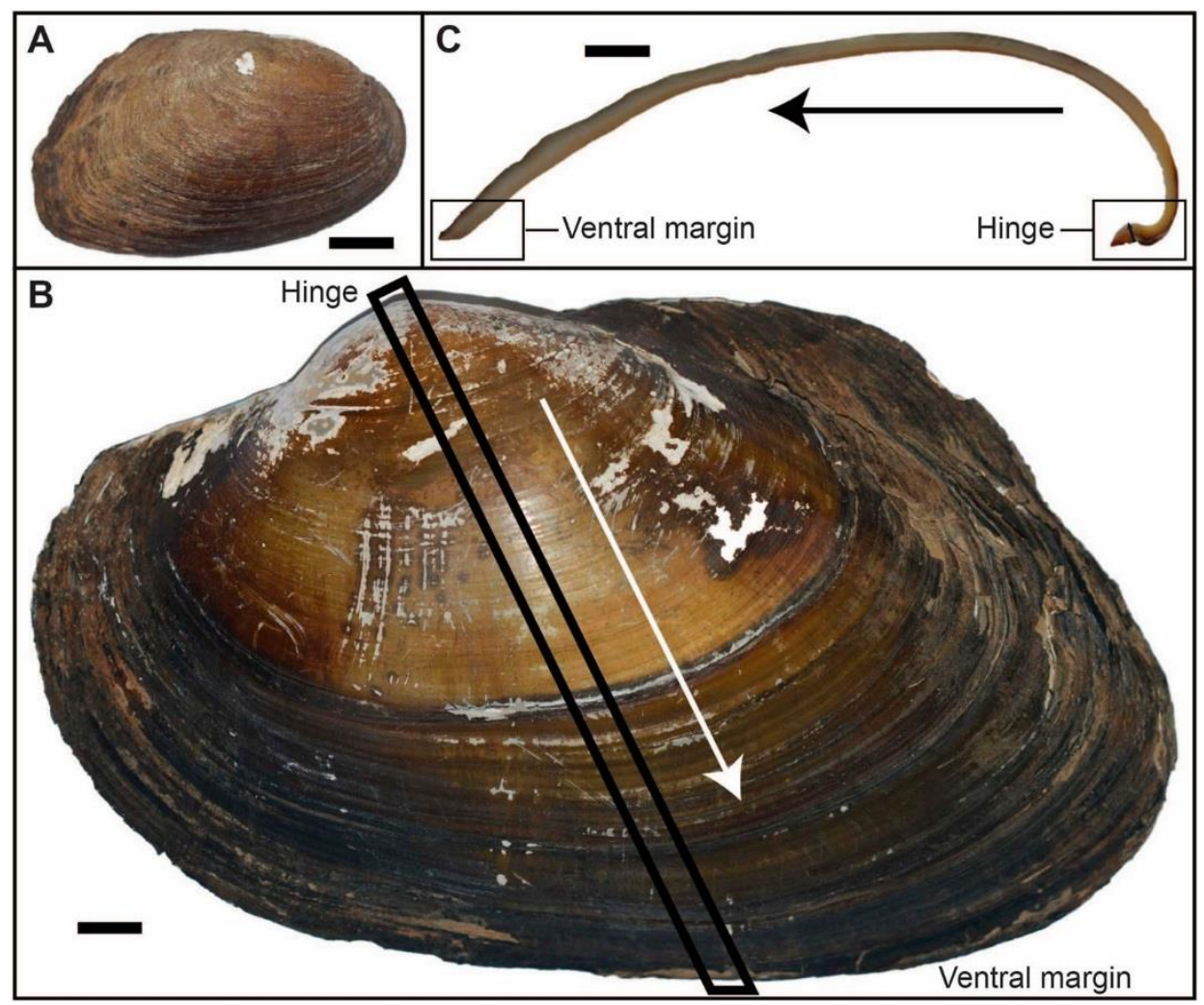

Figure 3. Shells of the two studied bivalve species: (A) Anodontites elongatus (Ae-2). (B) Anodontites trapesialis (At-1). The box shows the position of the shell cross-section removed along the axis of maximum growth. (C) Shell cross-section. Arrows in $B$ and $C$ indicate the growth direction. Scale bars are $1 \mathrm{~cm}$.

\subsection{Microdrilling and oxygen isotope analysis}

Samples for oxygen isotope measurements were drilled in the hinge using a computermonitored microdrilling equipment (New Wave® Micromill) at the 'Muséum National d'Histoire Naturelle' (MNHN) in Paris. Growth increments separated by growth lines were observed in all hinges viewed using an optical microscope under diffused light. The hinges were sampled continuously from the internal to the external part of the shell taking care to maintain each sampling groove parallel to growth lines. The distance between successive grooves was determined to provide enough carbonate powder for a valid oxygen isotope analysis and an infra-seasonal resolution assuming that growth lines, corresponding to a growth cessation or important slow down [32], were annual due to the clear seasonal Amazonian environmental variability (characterised by alternation of dry and wet seasons). Grooves were about $60 \mu \mathrm{m}$-large for approximately $3 \mathrm{~mm}$ long. Carbonate powder weighted $41 \pm 26 \mu \mathrm{g}(\mathrm{n}=129)$. On average, 9 and 6 sampling grooves were done per growth increment for $A$. trapesialis and $A$. elongatus, respectively. Carbonate powder samples were reacted with orthophosphoric acid at $70{ }^{\circ} \mathrm{C}$, and $\delta^{18} \mathrm{O}$ s values were measured using a VG SIRA 9 mass spectrometer coupled to a ThermoKiel IV carbonate device at the Institut des Sciences de la Terre de Paris (ISTeP, University Paris VI). $\delta^{18} \mathrm{Os}$ is expressed in per mille (\%o standardised against the Vienna PeeDee Belemnite - VPDB standard). Since Anodontites sp. shells are aragonitic, we used the Kim et al. [33] equation to calculate the acid fractionation factor for aragonite at $70{ }^{\circ} \mathrm{C}$ and corrected our $\delta^{18} \mathrm{O}$ s isotope values accordingly. The analytical 
precision was $0.03 \%$ for $\delta^{18} \mathrm{Os}(1 \sigma$ of NBS19 standard measurements done every 10 shell samples, $n=129$ in total; NBS19 V-PDB values are $\delta^{18} \mathrm{O}=-2.20 \%$ ). All isotope data, including non-presented $\delta^{13} \mathrm{C}_{\mathrm{S}}$, have been deposited in the information system Zenodo (DOI: 10.5281/zenodo.1217596).

\subsection{Data analysis}

Before undertaking parametric statistical tests, normality of the distribution and equality of variances of data were verified using the Shapiro-Wilk and F-tests, respectively. Nested two-way ANOVA were then done to test the significance of the differences in isotope values between the two specimens of each Anodontites species and between the two species/sites. All analyses were done using the statistical package $R$ version 3.3.0 ( $R$ Core Team, 2017). A significance threshold of $\alpha=0.05$ was adopted for all statistical tests.

\section{Results}

\subsection{Hinge growth patterns}

In A. trapesialis, 4 and 5 growth lines and growth increments were counted for At-1 and At-2 hinges, respectively (Figure $4(a, b)$ ). In the hinge of $A$. elongatus Ae-1, 8 growth lines and 7 growth increments were observed (Figure 4(c)) and 3 growth lines and 4 growth increments for specimen Ae-2 (Figure 4(d)).

\section{2. $\delta^{18}$ Os intraspecific and temporal variability}

On average, there was no significant isotope composition difference between shells of the same species that had grown presumably at the same site ( $p$-value $>0.05$; Table 3 ). However, average oxygen isotope values significantly differed between the two species collected in two different sites. Mean $\delta^{18} \mathrm{Os}( \pm \mathrm{SD})$ and range were significantly higher in $A$. trapesialis shells from Brazil $\left(\delta^{18} \mathrm{Os}=-4.42 \pm 1.74 \%\right.$; $6.70 \%$ ) than in $A$. elongatus from Peru $\left(\delta^{18} \mathrm{O}_{s}=-6.23 \pm 0.73 \% ; 3.28 \%\right.$ ) ( $p$-value $\left.<0.001\right)$ (see Table 3 for specimen's data). All shells presented isotope cyclicity with one cycle defined as the isotope variations comprised between two successive lowest $\delta^{18} \mathrm{O}$ s values. Cyclic amplitude was calculated as the difference between the highest and the lowest values of each $\delta^{18} \mathrm{O}$ s cycle within a shell. Cyclic variations were higher in $A$. trapesialis than in $A$. elongatus with mean amplitudes of $4.46 \pm 1.37$ vs. $1.59 \pm 0.77 \%$ (Figure 5, Table 3). At-1 and At-2 presented 3 and 4 cycles, respectively. The more negative $\delta^{18} \mathrm{O}_{\mathrm{s}}$ values corresponded to growth lines and the more positive to growth increments. A positive trend on $\delta^{18} \mathrm{O}$ s was observed in At-1 (Figure 5). For $A$. elongatus, 4 cycles per shell were counted (Figure 5). Low $\delta^{18} \mathrm{O}$ s in $A e-1$ corresponded to growth lines, except for growth line $n^{\circ} 2$; while $\delta^{18}$ Os variations did not match the growth pattern in Ae-2 (Figure 5). 
A

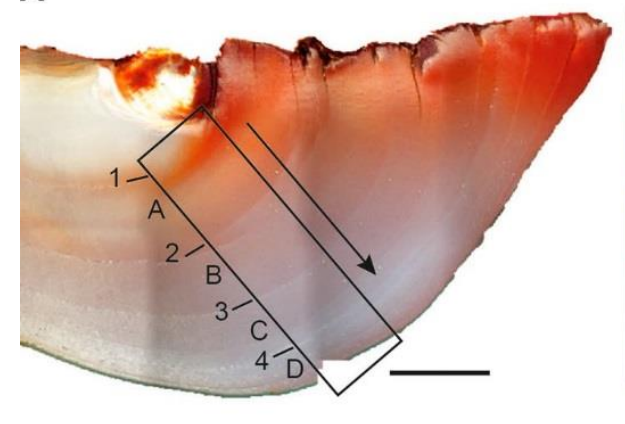

C

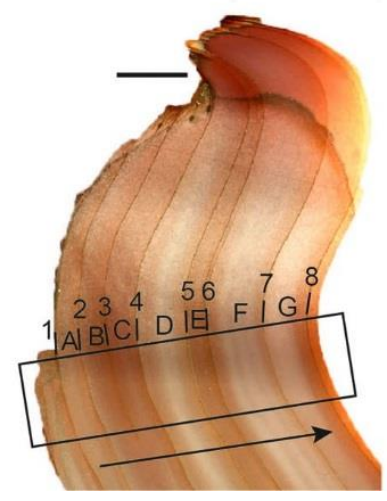

B

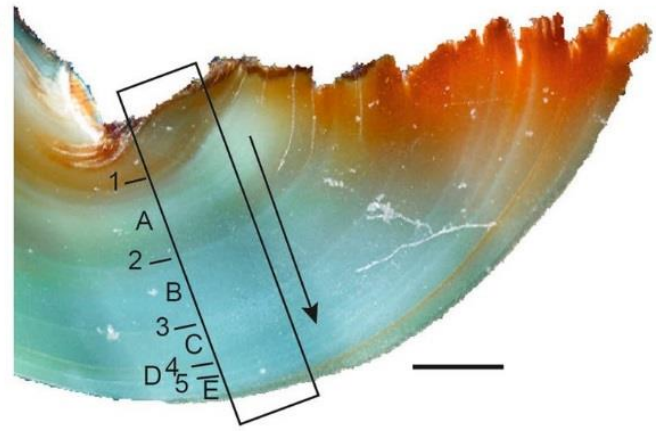

D

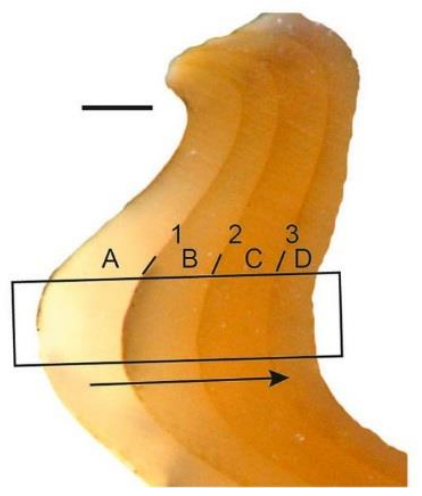

Figure 4. Growth patterns in the hinge of the $A$. trapesialis and $A$. elongatus specimens. Hinge cross sections of the two A. trapesialis At-1 (A) and At-2 (B) and the two A. elongatus Ae-1 (C) and Ae-2 (D) viewed under an optical microscope under diffused light. Numbers and letters indicate successive growth lines and increments from the inner to the outer part of the hinge. Arrows indicate the growth direction. Each picture is independent, i.e. the same number/letter does not correspond to the same year of growth line/increment formation. Scale bars are $1 \mathrm{~mm}$. Increments were noted by a letter and growth lines were numbered. The code 'A1' represents thus the oldest part of the shell.

Table 3. Oxygen isotopes data $\left(\delta^{18} \mathrm{Os}\right)$ obtained in the hinge of the 4 Anodontites spp. specimens. The cyclic amplitude in $\delta^{18} \mathrm{O}$ s is expressed as the mean (SD) of the range between the highest (Max) and the lowest (Min) values of each $\delta^{18}$ Os cycle. SD: standard deviation. N: number of analysed carbonate powder samples. n: number of cycles per species.

$$
\delta^{18} \mathrm{Os}_{\mathrm{s}}(\% \mathrm{~V} \text {-PDB })
$$

Mean $\delta^{18}$ Os cyclic variability (\%o V-PDB)

\begin{tabular}{|c|c|c|c|c|c|c|c|c|}
\hline Specimen & & Mean (SD) & Min & $\operatorname{Max}$ & Range & $\overline{\operatorname{Min}(S D)}$ & $\operatorname{Max}(S D)$ & Amplitude (SD) \\
\hline$\overline{A t-1}$ & 29 & $-4.39(1.83)$ & -8.01 & -1.31 & 6.70 & $-6.49(1.09)$ & $-2.00(0.93)$ & $4.49(1.37)$ \\
\hline $\begin{array}{l}\mathrm{At}-2 \\
\mathrm{Ae}-1 \\
\mathrm{Ae}-2\end{array}$ & $\begin{array}{l}37 \\
33 \\
30\end{array}$ & $\begin{array}{l}-4.45(1.70) \\
-6.24(0.75) \\
-6.23(0.71)\end{array}$ & $\begin{array}{l}-7.85 \\
-7.52 \\
-7.66\end{array}$ & $\begin{array}{l}-1.73 \\
-4.38 \\
-4.77\end{array}$ & $\begin{array}{l}6.12 \\
3.14 \\
2.90\end{array}$ & $-6.67(0.32)$ & $\begin{array}{l}n=7 \\
-5.09(0.60) \\
n=8\end{array}$ & $1.58(0.77)$ \\
\hline
\end{tabular}



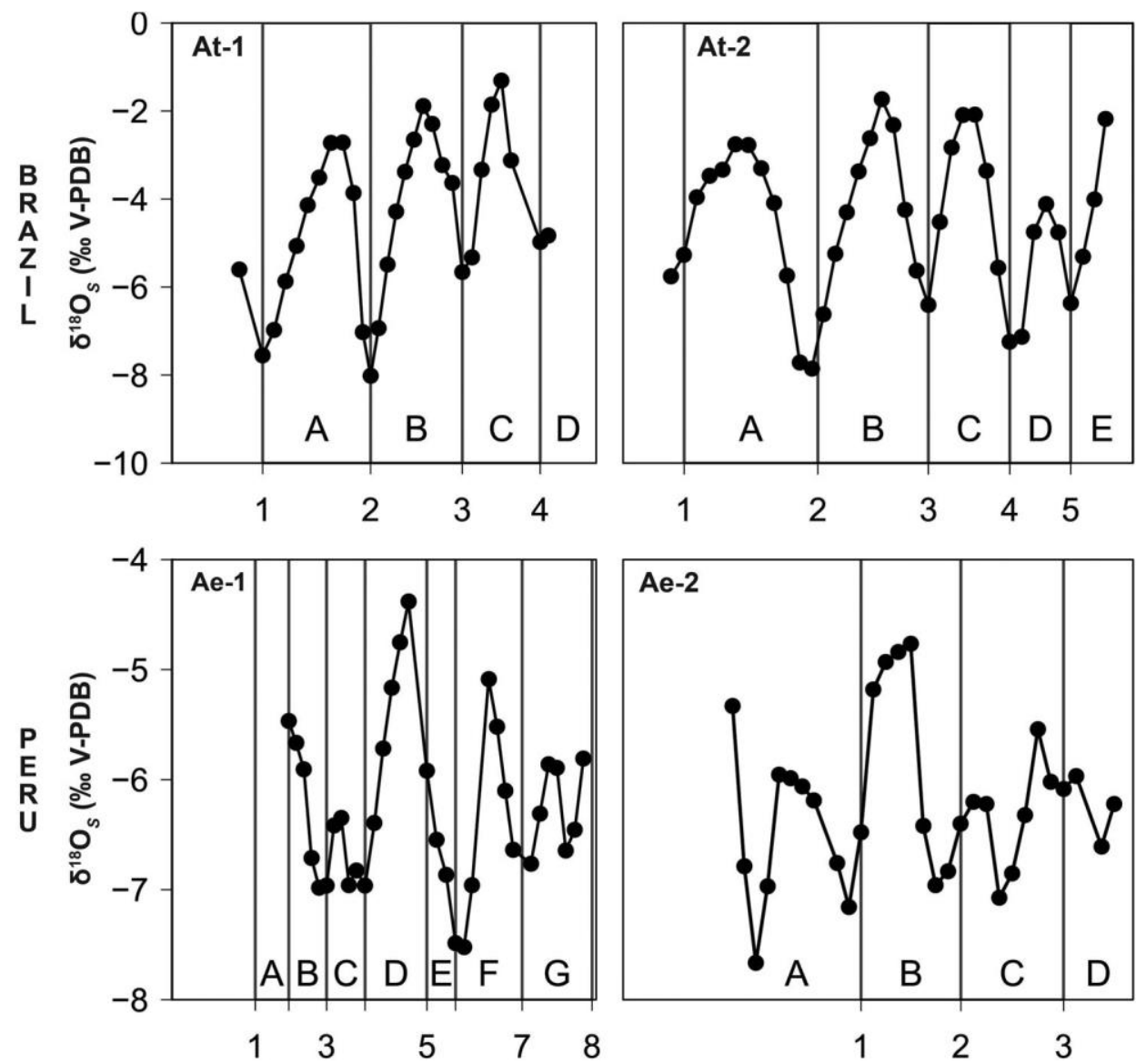

Figure $5 . \delta^{18} \mathrm{Os}$ (in \%o V-PDB) proftes in the hinge of the two A. trapesialis (At-1 and At-2) and the two A. elongatus (Ae-1 and Ae-2). Numbers and letters indicate successive growth lines and increments as in Figure 4.

\section{Discussion}

\section{1. $\delta^{18} \mathrm{O}$ s variations and growth pattern}

It has been shown in many bivalve species that shell growth patterns can be used to give an age to the shell as well as to reconstruct environmental parameter (e.g. water temperature) changes [34]. In freshwater unionid bivalve shells that lived in lake or floodplain lake, growth decreases or cessations were linked to high water turbidity related to high discharge events $[22,34]$. In the two Brazilian $A$. trapesialis specimens presented here, the lowest $\delta^{18}$ Os values, supposedly characteristics of the wet season (see below), occurred at the time of growth line deposition. This season is marked by turbulent waters and high amount of suspended material (HYBAM database, data not shown, http://www.ore- hybam.org/index.php/eng/Data). The shape of the $A$. trapesialis $\delta^{18} \mathrm{O}$ profiles appears similar to that obtained in shells that present a seasonal-related growth decrease. The 'constant-winter/summer-shutdown' model established by Goodwin et al. [19], defined for shells in temperate climate, could thus be transposed here in a 'wet-shutdown' model for environments characterised by the alternating of wet and dry seasons. Consequently, the growth lines in our $A$. trapesialis shells are most probably the mark of the wet season growth slowdown.

In A. elongatus from Peru, interpretation of the occurrences of growth lines in relation with the 
environmental seasonality is more complex than in Brazilian A. trapesialis. There was no clear correspondence between $\delta^{18} \mathrm{O}$ s profiles and growth pattern. One to two cycles were seen per presumed annual increment, and the lowest/highest values in $\delta^{18} \mathrm{O}_{s}$ did not necessarily match observed growth lines. Therefore, no definitive conclusion can be drawn for this species yet.

\section{2. $\delta^{18} \mathrm{O}$ s reproducibility}

Shells of $A$. trapesialis were collected in the same lake in Brazil and thus lived in the same environmental conditions. Similarly, $A$. elongatus were collected in the same lake in Peru. Reproducibility assessed by statistical analyses (Table 3 ) and by similar variability of the $\delta^{18} \mathrm{Os}$ profiles (Figure 5) leads us to conclude that the $\delta^{18} \mathrm{O}$ s variations observed in Anodontites spp. shells are mostly governed by environmental forcing (see Section 4.3), as observed by Kaandorp et al. [22].

Considering the two $A$. trapesialis shells, we observe that At-1 presents a trend of increasing $\delta^{18} \mathrm{O}$ s values compared to At-2. Such tendency may represent an evolution of the $\delta^{18} \mathrm{Os}$ fractionation related to the animal, either an ontogenic trend or other unknown individual effects (i.e. disease, specific behaviour). Since shells have a very similar size, an age-component effect can be excluded. This trend could not result from a change in water chemistry linked for example to hydrological variations such as an inter-annual increase/decrease in discharge over several years. Firstly, shells lived in the same lake and should thus have recorded the same environmental variations. Secondly, although Marengo and Espinoza Villar [6] concluded to an increasing frequency of extreme hydrological events in the last two decades for the Amazon region, no clear tendency on average flow in the Solimões river for the 1996-2017 period could be detected (J. Ronchail, pers. comm. based on HYBAM database). The other 3 shells did not present such a trend, indicating that an individual effect is the most probable. Therefore, studies using bivalve shells to reconstruct geochemical baseline of complex freshwater environments like those encountered in the Amazon basin would probably have to consider a specific number of individuals or species, which remains to be defined, to avoid or correct for individual physiologic effect.

\section{3. $\delta^{18} \mathrm{O}$ s and environmental variations}

The $\delta^{18} \mathrm{O}$ variations observed in the two Anodontites sp. reported here exhibit quite distinct patterns. We argue that the observed differences reflect the environmental conditions under which they have grown, thus indicating the potential use of these shells as proxy of past hydrological variability. The $A$. trapesialis shells were collected in a lake located in the Ilha da Paciencia (Brazil) that is strongly affected by the Solimões river seasonal dynamics. In this regard, these samples had grown in an environment similar to the floodplain described by Kaandorp et al. [22]. During the rainy season, the Ilha da Paciencia floodplain lake water level is high because, in addition to the precipitation, it is fed by the Solimões river waters. During this period of the year, the river and precipitation waters have the lowest values of the year (Figure 2, Table 2). In contrast, during the dry season, the river level drops and the floodplain lake becomes disconnected from the mainstream, thus becoming strongly affected by the combined effect of highly $\delta^{18} \mathrm{O}$-enriched precipitation $\left(\delta^{18} \mathrm{O}_{P}=-1.80 \pm\right.$ $1.46 \%$ at the height of the dry season, August) and ${ }^{18} \mathrm{O}$ water enrichment related to evaporation [35]. Consequently, water $\delta^{18} \mathrm{O}$ variations in such lakes are high and seasonal, reflecting the disconnection from the mainstream during several months a year. Yet, the $A$. trapesialis shells have an average $\delta^{18} \mathrm{Os}$ of $-4.42 \%$ and a $\delta^{18} \mathrm{O}$ s amplitude of $4.49 \%$ (Table 3) similar to the local precipitation, which has an average $\delta^{18} \mathrm{O}_{p}$ of $-4 .{ }^{18} \%$ and $a \delta^{18} \mathrm{O}_{\mathrm{P}}$ amplitude of $5.38 \%$ different from the river oxygen isotope signature 
(average $\delta^{18} \mathrm{O}_{\mathrm{s}}=-5.59 \% ; \delta^{18} \mathrm{O}_{\mathrm{R}}$ amplitude $=1.78 \%$; Table 2, Figure 2). We thus conclude that the large $\delta^{18} \mathrm{O}$ s range observed in A. trapesialis of this study, as in Kaandorp et al. [22], reflect elevated isotopic variations of floodplain lake, confirming the potential of this species $\delta^{18} \mathrm{O}$ s as a proxy of water $\delta^{18} \mathrm{O}$ variations in such complex environments.

Conversely, A. elongatus shells collected along the Rio Amazonas near lquitos (Peru) present far less variable $\delta^{18}$ Os values (Figure 6) with a mean seasonal amplitude of 1.58 $\%$ (Table 3), which is almost three times smaller than that observed in A. trapesialis shells from the Ilha da Paciencia floodplain lake (4.49\%; Table 3) and very different from the local precipitation one (7.03\%; Table 2, Figure 2). Even not ruling out the possibility of a species-specific effect, we argue that the narrow range of $\delta^{18} \mathrm{Os}$ observed in $A$. elongatus, when compared with $A$. trapesialis from llha da Paciencia and from Kaandorp et al. [22], indicates that the habitat of these shells was largely influenced by the main river course water.

To further support the above conclusions, we calculated theoretical shell $\delta^{18} \mathrm{O}$ values $\left(\delta^{18} \mathrm{O}_{\mathrm{AR}}\right)$ for two environmental end-members, i.e. floodplain lake and river, for the two seasonal extremes, i.e. wet and dry, using the Grossman and Ku [36] thermometry equation established for molluscs $\left(\mathrm{T}\left({ }^{\circ} \mathrm{C}\right)=21.8-4.69\left(\delta^{18} \mathrm{O} s-\delta^{18} \mathrm{O} w\right)\right)$. Environmental data for the floodplain lake end-member were taken from Kaandorp et al. [22] with $\delta^{18} \mathrm{Ow}$ and water temperature data corresponding to the maximum (minimum) lake water depth for wet(dry) season theoretical $\delta^{18} \mathrm{O}_{A R}$ value calculations. For the river endmember, we took environmental data from the Manaus station. Wet (March) and dry (August) season months were set up to March and August based on maximal and minimal average precipitation amount per month on the whole dataset (Table 2).

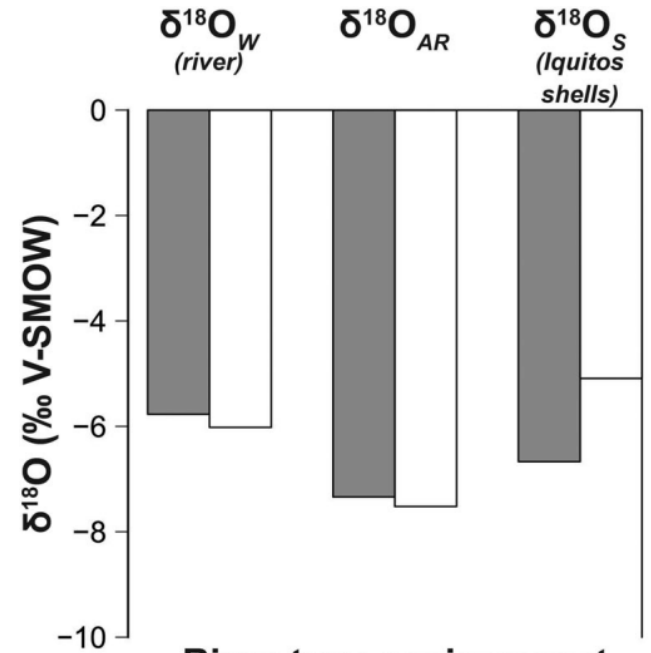

River-type environment

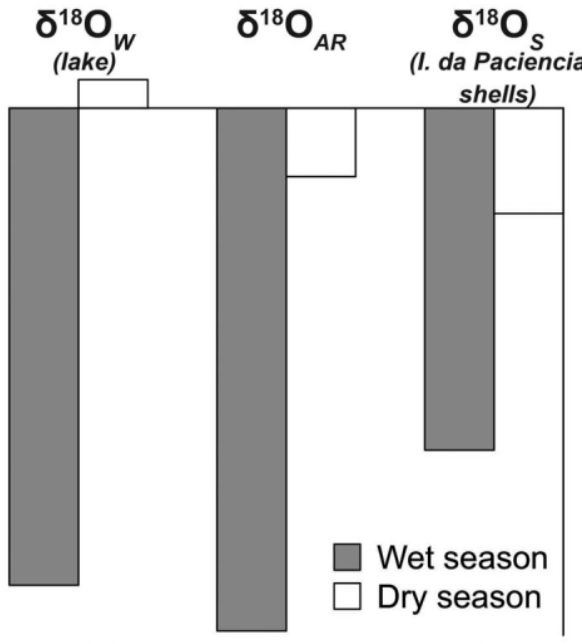

FPL-type environment

Figure 6. Wet and dry seasons shell theoretical $\left(\delta^{18} \mathrm{O}_{A R}\right)$ and observed $\delta^{18} \mathrm{O}_{s}$ signatures for two Amazonian end-members, river $(A)$ and floodplain lake $(B) . \delta^{18} O_{A R}$ were calculated using the Grossman and $\mathrm{Ku}[36]$ equation for molluscs. Floodplain lake environmental data were taken from Kaandorp et al. [22] and river ones from the Manaus station (see text for details).

To compare with our shell data, we averaged the lowest and highest $\delta^{18} \mathrm{O}$ s values for each species (Table 3; Figure 6). The difference in theoretical $\delta^{18} \mathrm{O}_{A R}$ values between wet and dry season for the river end-member is low and compare with data obtained in our $A$. elongatus shells from lquitos. This is the opposite for our $A$. trapesialis shells from Manaus that mimic $\delta^{18} \mathrm{O}_{\mathrm{AR}}$ values calculated from the floodplain lake end-member environmental data (Figure 6). Note that modifying the temperature amplitude does not 
change the $\delta^{18} \mathrm{O}_{A R}$ above results, confirming the limited influence of water temperature on $\delta^{18} \mathrm{O} s$ signature in such hydrologically contrasted environments. Thus, the calculation of theoretical $\delta^{18} \mathrm{O}_{\mathrm{AR}}$ for floodplain lake and river endmembers confirms our above deductions done considering environmental data, hydrological functioning, and Kaandorp et al. [22] work.

\section{Conclusion}

The Amazon basin hydrology is a complex system that depends on multiple processes like precipitation amount, evapotranspiration, and mix of different water sources depending on the location (e.g. floodplain lake vs. main stream). Those processes are reflected in the water $\delta^{18} \mathrm{O}$ signature that can be retrieved at the seasonal scale using Anodontites spp. bivalve shells, which have low seasonal $\delta^{18} \mathrm{O}$ variability when living in or close to the river's mainstream and high seasonal $\delta^{18} \mathrm{O}$ variability when living in the floodplain, or in a floodplain lake (varzea), seasonally disconnected from the river.

These results are promising for the use of such archives to retrieve hydrological data in various and numerous sites. Indeed, depending on the $\delta^{18} \mathrm{Os}$ of the specimens, one will be able to decipher the hydrologic functioning at the collection site (floodplain, floodplain lake, mainstream) for actual or past conditions, that is very interesting in the Amazon basin in which some rivers present an intense geomorphological dynamic (e.g. frequent mainstream moving, oxbow lakes creation and recovery). One might also be able to retrieve water $\delta^{18} \mathrm{O}_{\mathrm{P}}$ or $\delta^{18} \mathrm{O}_{\mathrm{R}}$ values, at least at a seasonal resolution over several years, for highly contrasted sites (floodplain lake vs. mainstream) that might replace costly and complex monitoring procedures. Our results also encourage the expansion of such studies to other chemical elements (e.g. barium, strontium, magnesium) to use Anodontites spp. shells for reconstruction of biogeochemical conditions and variations of the Amazon. In addition, the understanding of infra-seasonal variations in shell composition in the present climate will help decrypt seasonal variations in the past, based on dated fossil shells.

\section{Acknowledgments}

We are grateful to Lorenzo Barocco and Ivanildo L.A. Santos from UFAM (Manaus) and Carmen R.G. Davila (Instituto de Investigaciones de la Amazonía Peruana - IIAP, Iquitos) from Peru who helped for shells sampling. We also thank Nathalie Labourdette for isotope analyses at ISTeP, Paris VI.

The Version of Record of this manuscript has been published and is available in "Isotopes in Environmental and Health Studies" 18 Sep 2019, https://www.tandfonline.com/doi/full/10.1080/10256016.2019.1666120.

\section{Funding}

We thank national institutions that supported our work through PEPS (CNRS - BiBhy project) and EC2CO (INSU - BiEauAmaz project) funding programmes.

\section{References}

[1] Filizola N, Guyot JL. Suspended sediment yields in the Amazon basin: an assessment using the Brazilian national data set. Hydrol Process. 2009;23(22):3207-3215.

[2] Moreira-Turcq P, Seyler P, Guyot JL, et al. Exportation of organic carbon from the Amazon River and 
its main tributaries. Hydrol Process. 2003;17(7):1329-1344.

[3] Castello L, McGrath DG, Hess LL, et al. The vulnerability of Amazon freshwater ecosystems. Conserv Lett. 2013;6(4):217-229.

[4] Ronchail J, Espinoza JC, Drapeau G, et al. The flood recession period in Western Amazonia and its variability during the 1985-2015 period. J Hydrol Reg Stud. 2018;15:16-30.

[5] Espinoza Villar JC, Ronchail J, Guyot JL, et al. Climate variability and extreme drought in the upper Solimoes River (western Amazon Basin): understanding the exceptional 2010 drought. Geophys Res Lett. 2011;38(13):L13406.

[6] Marengo JA, Espinoza Villar JC. Extreme seasonal droughts and floods in Amazonia: causes, trends and impacts. Int J Climatol. 2016;36(3):1033-1050.

[7] Gaillardet J, Dupre B, Allegre CJ, et al. Chemical and physical denudation in the Amazon River Basin. Chem Geol. 1997;142(3):141-173.

[8] Poitrasson F, Vieira LC, Seyler P, et al. Iron isotope composition of the bulk waters and sediments from the Amazon River Basin. Chem Geol. 2014;377:1-11.

[9] Seyler PT, Boaventura GR. Distribution and partition of trace metals in the Amazon basin. Hydrol Process. 2003;17(7):1345-1361.

[10] Dellinger M, Gaillardet J, Bouchez J, et al. Lithium isotopes in large rivers reveal the cannibalistic nature of modern continental weathering and erosion. Earth Planet Sci Lett. 2014;401:359-372.

[11] Duponchelle F, Pouilly M, Pécheyran C, et al. Trans-Amazonian natal homing in giant catfish. J App Ecol. 2016;53:1511-1520.

[12] Cao YJ, Tang CY, Cao GM, et al. Hydrochemical zoning: natural and anthropogenic origins of the major elements in the surface water of Taizi River Basin, Northeast China. Environ Earth Sci. 2016;75:811. https://doi.org/10.1007/s12665-016-5469-9

[13] Pouilly M, Point D, Sondag F, et al. Geographical origin of Amazonian freshwater fishes fingerprinted by ${ }^{87} \mathrm{Sr} /{ }^{86} \mathrm{Sr}$ ratios on fish otoliths and scales. Environ Sci Technol. 2014;48(16):8980-8987.

[14] Sousa RGC, Humston R, Freitas CEC. Movement patterns of adult peacock bass Cichla temensis between tributaries of the middle Negro River basin (Amazonas - Brazil): an otolith geochemical analysis. Fisheries Manag Ecol. 2016;23(1):76-87.

[15] Goulding M, Barthem R, Ferreira EJG. Smithsonian Atlas of the Amazon. 1st ed. Washington (DC): Smithsonian Books; 2003.

[16] Santos RV, Sondag F, Cochonneau G, et al. Source area and seasonal ${ }^{87} \mathrm{Sr} /{ }^{86} \mathrm{Sr}$ variations in rivers of the Amazon basin. Hydrol Process. 2014;29(2):187-197.

[17] Butler PG, Schöne BR. New research in the methods and applications of sclerochronology. Palaeogeogr Palaeoclimatol Palaeoecol. 2017;465:295-299.

[18] Schöne BR, Gillikin DP. Unraveling environmental histories from skeletal diaries - advances in sclerochronology. Palaeogeogr Palaeoclimatol Palaeoecol. 2013;373:1-5.

[19] Goodwin DH, Schöne BR, Dettman DL. Resolution and fidelity of oxygen isotopes as paleotemperature proxies in bivalve mollusk shells: models and observations. Palaios. 2003;18(2):110-125.

[20] Schöne BR, Surge D. Looking back over skeletal diaries - high-resolution environmental reconstructions from accretionary hard parts of aquatic organisms. Palaeogeogr Palaeoclimatol Palaeoecol. 2005;228(1-2):1-3.

[21] Dettman DL, Flessa KW, Roopnarine PD, et al. The use of oxygen isotope variation in shells of estuarine mollusks as a quantitative record of seasonal and annual Colorado River discharge. Geochim Cosmochim Acta. 2004;68(6):1253-1263.

[22] Kaandorp RJG, Vonhof HB, Del Busto C, et al. Seasonal stable isotope variations of the modern Amazonian freshwater bivalve Anodontites trapesialis. Palaeogeogr Palaeoclimatol Palaeoecol.

2003;194(4):339-354.

[23] O'Neil DD, Gillikin DP. Do freshwater mussel shells record road-salt pollution? Sci Rep. $2014 ; 4: 7168$.

[24] Versteegh EAA, Vonhof HB, Troelstra SR, et al. Seasonally resolved growth of freshwater bivalves determined by oxygen and carbon isotope shell chemistry. Geochem Geophys Geosyst. 2010;11(8):Q08022.

[25] Vonhof HB, Joordens JCA, Noback ML, et al. Environmental and climatic control on seasonal stable isotope variation of freshwater molluscan bivalves in the Turkana Basin (Kenya). Palaeogeogr Palaeoclimatol Palaeoecol. 2013;383:16-26.

[26] Abell PI, Amegashitsi L, Ochumba PBO. The shells of Etheria elliptica as recorders of seasonality at Lake Victoria. Palaeogeogr Palaeoclimatol Palaeoecol. 1996;119(3-4):215-219.

[27] Dettman DL, Reische AK, Lohmann KC. Controls on the stable isotope composition of seasonal 
growth bands in aragonitic fresh-water bivalves (unionidae). Geochim Cosmochim Acta. 1999;63:1049-1057.

[28] Kaandorp RJG, Vonhof HB, Wesselingh FP, et al. Seasonal Amazonian rainfall variation in the Miocene Climate Optimum. Palaeogeogr Palaeoclimatol Palaeoecol. 2005;221(1-2):1-6.

[29] Kaandorp RJG, Wesselingh FP, Vonhof HB. Ecological implications from geochemical records of Miocene Western Amazonian bivalves. J S Am Earth Sci. 2006;21(1-2):54-74.

[30] Vonhof HB, Wesselingh FP, Ganssen GM. Reconstruction of the Miocene western Amazonian aquatic system using molluscan isotopic signatures. Palaeogeogr Palaeoclimatol Palaeoecol. 1998;141:85-93.

[31] Vonhof HB, Wesselingh FP, Kaandorp RJG, et al. Paleogeography of Miocene Western Amazonia: isotopic composition of molluscan shells constrains the influence of marine incursions. Geol Soc Am Bull. 2003;115(8):983-993.

[32] Rhoads DC, Lutz RA. Skeletal growth of aquatic organisms: biological records of environmental change. New York: Plenum Press; 1980.

[33] Kim S-T, Mucci A, Taylor BE. Phosphoric acid fractionation factors for calcite and aragonite between 25 and $75^{\circ} \mathrm{C}$ : Revisited. Chem Geol. 2007;246(3-4):135-146.

[34] Kelemen Z, Gillikin DP, Graniero LE, et al. Calibration of hydroclimate proxies in freshwater bivalve shells from Central and West Africa. Geochim Cosmochim Acta. 2017;208:41-62.

[35] Hoefs J. Stable isotope geochemistry. 6th ed. Berlin, Heidelberg: Springer; 2009.

[36] Grossman EL, Ku T-L. Oxygen and carbon isotope fractionation in biogenic aragonite: temperature effects. Chem Geol. 1986;59:59-74. 